Available online at

http://journal.ugm.ac.id/jifnp
INDONESIAN FOOD AND NUTRITION PROCRESS

Indonesian Food and Nutrition Progress, 2017, Vol. 14, Issue 1

\title{
Extract Corn Silk with Variation of Solvents on Yield, Total Phenolics, Total Flavonoids and Antioxidant Activity
}

\author{
Haslina*) and Murtiari Eva \\ Faculty of Agriculture Technology, Semarang University, Semarang, Indonesia \\ ${ }^{*}$ Corresponding author, email address: chana_panca@yahoo.com
}

Received 23 Jan 2017; Accepted 12 May 2017; Published Online 15 May 2017

\begin{abstract}
Corn silk is a by product that is commonly used as a traditional medicine that contains bioactive compounds such as volatile oils, steroids, alkaloids, tannins, flavonoids, chlorogenic acid and phenolic compounds, containing minerals, high crude fiber, vitamins (B, C, and K), steroids such as sitosterol and stigmasterol, alkaloids, saponins, tannins, flavonoids, anthocyanins, etc. The solvent used for the extraction of flavonoid compounds are methanol, ethanol, acetone and ethyl acetate. Basic separation by solvent extraction is the difference in the solubility of each composition in compaction with solvent. Solubility is influenced temperature, stirring speed, the extraction time, comprehensive tangent plane solids by solvent extraction and frequency. This study aims to extract corn silk by using a variation of the solvent type in terms of yield, total phenols, flavonoids and antioxidant activity. The variations of solvent are methanol: water; ethanol: water; ethyl acetate:water, acetone: water, $(85: 15, \mathrm{v} / \mathrm{v})$. Variations in the type of solvent with the highest yield at a ratio methanol:water, and the ratio ethanol:water, then the ratio acetone:water and the lowest ratio of ethyl acetate:water. At ratio methanol:water obtained yield is $65.8 \%$, total phenol is $45350.27 \mathrm{mg} / \mathrm{kg} \mathrm{GAE}$, total flavonoids is $291.28 \mathrm{mg} \mathrm{QE} / \mathrm{kg}$ and activities of antioxidant is $92.1 \%$.
\end{abstract}

Keywords: corn silk, solvent, yield, total phenol, total flavonoid and antioxidant activity

\section{Introduction}

One of the plants currently known to be able to be used as traditional medicine to decrease cholesterol level in the blood is corn (Zea mays), namely on the part of the corn silk (Wiryowidagdo and Sitanggang, 2004).

Corn silk is by-product or waste commonly used as traditional medicine such as urine laxative and blood pressure reducer (Nuridayanti, 2011) which contains bioactive compounds such as volatile oils, steroids, alkaloids, tannins, flavonoids, chlorogenic acid and other phenolic compounds (Bushman, 2002; Liu et al., 2011), containing protein, carbohydrates, minerals $(\mathrm{Ca}, \mathrm{Mg}, \mathrm{Cu}, \mathrm{Zn}, \mathrm{Fe}$ and $\mathrm{Mn}$ ), high crude fiber, $B$ vitamins, $C$ vitamins, $\mathrm{K}$ vitamins, steroids such as sitosterol and stigmasterol, alkaloids, saponins, tannins, flavonoids, anthocyanins, protonate in, vanillic acid, derivatives hasperidin and quercetin (Nurhanan and Rosli, 2014, Ebrahimzadeh et al., 2008; Guo et al., 2009), phenols, terpenoids and glycosides (Sholihah et al., 2012), maysin, $\beta$-carotene, beta-sitosterol, geraniol, hordenin, limonene, menthol and viteskin (Rahmayani, 2007) also source of polyphenol that is good as antioxidant (Nurhanan et al., 2012). Wang et al., (2011) explains that corn silk contains water $9.65 \%$, protein $17.6 \%$, fat $0.29 \%$, ash $3.91 \%$ and crude fiber $40 \%$. 
The solvents often used for the extraction of flavonoids are methanol, ethanol, acetone and ethyl acetate. The results of Tong-Wei et al., (2011) showed that the highest inhibition activity was in the active component of corn silk which were purified with $50 \%$ ethanol with the inhibition activity of $69.90 \% \pm 1.27 \%$. Nurhanan et al., (2012) extracted antioxidant components from corn silk by using methanol and water with a number of polyphenols in the extracts of methanol and water respectively were 272.81 $\mathrm{mg}$ GAE/100 g and $256.36 \mathrm{mg}$ GAE/100 mg (dry). While the research results of Bangoura et al., (2013) stated that acetone was the most effective solvent to extract the antioxidants from foxtail millet (a kind of cereal) compared to water solvent, ethanol, propanol, and methanol. A combination solvent of ethyl acetate:water $(85: 15, v / v)$ generated total flavonoids figure is four times larger than the solvent acetone in the extraction of organic compounds from grape seeds (Jayaprakasha, 2001). While Akcay, (2011) chose methanol $70 \%(\mathrm{v} / \mathrm{v})$, with a ratio of $10: 1(\mathrm{v} / \mathrm{w})$ of the material for the purpose and the same material. The reason for separation of extraction with solvent was the difference in the solubility of each composition in compaction with solvent. This solubility was influenced by temperature, stirring speed, the extraction time, the wide of tangent plane solids with solvent and extraction frequency. According to Chew et al., (2011), there were several factors that contribute the rate and quality of extraction on bioactive compounds component of phenol compound namely the type of solvent extraction, solvent concentration, particle size, temperature, $\mathrm{pH}$ and extraction time.

\section{Materials and Methods}

Some equipment used were becker glass, blender, water bath, spectrophotometer, $\mathrm{pH}$ meter, oven, water bath shaker (extraction), Whatman filter paper no.1, rotary flash evaporator, Folin-Ciocalteu colorimetric and some glass tools for analysis. The raw material in this study was sweet corn silk at the age of $80 \pm 90$ days obtained from Pati, Central Java. The solvents used in this study were water, methanol, ethanol, ethyl acetate, and acetone.

\section{Sample Preparation}

Fresh corn silk was washed with distilled water (aquadest) oven-dried at $60^{\circ} \mathrm{C}$ for 24 hours (Hu and Deng., 2011) until the content of final moisture was $10 \%$, mashed into powder using a grinder, vacuum packed and stored at $<-20^{\circ} \mathrm{C}$ until analyzed.

\section{Extraction of Corn Silk}

Three grams of corn silk powder were diluted with proportions of ingredients and the solvent 1:4 (Burin et. al., 2011) at room temperature for 24 hours by maceration. Ratio ethyl acetate:water was 85:15 (v/v) (Jayaprakasha, 2001).The extraction was done at $70^{\circ} \mathrm{C}$ with water bath shaker. The next $1.5 \mathrm{~h}$ then filtered, separated the waste. The separation of solvent was conducted by a rotary flash evaporator at $60^{\circ} \mathrm{C}(\mathrm{Li}, 2009)$. Dissolve the residue with methanol $5 \mathrm{~mL}$, save at $0-4^{0} \mathrm{C}$.

\section{Experimental Design}

The experimental design used in this study is Group Randomized Design (GRD) 1 factor with 5 times repeatings. The solvents:

1. Methanol: water $(85: 15, \mathrm{v} / \mathrm{v})$

2. Ethanol: water $(85: 15, \mathrm{v} / \mathrm{v})$

3. Ethyl Acetate: water $(85: 15, \mathrm{v} / \mathrm{v})$

4. Acetone: water $(85: 15, \mathrm{v} / \mathrm{v})$

Then, the data obtained were analyzed the variants and if there were differences among treatments, it would be continued with Duncan Multiple Range Test (DMRT) at $5 \%$ level. 
The observed parameters were rendement, total phenol, total flavonoid and antioxidant activity.

Yield

Yield is the final result or the amount of product calculated based on the final weight percentage of a product produced by the net weight of the raw materials used by extracts yield of corn silk, calculated by using the formula:

$$
\text { Yield }(\mathrm{db})=\frac{(\mathrm{A})}{(\mathrm{B})} \times 100 \%
$$

$A=$ extract weight produced $(\mathrm{mL})$

$B=$ the initial raw material weight

\section{Total Phenol}

Using Folin-Ciocalteu colorimetric method with gallic acid standards, which the results of the solvent were then analyzed with the spectrophotometer. Folin Ciocalteu reagent was diluted with distilled water at ratio 1:10, $0.5 \mathrm{~mL}$. Then corn silk extract was mixed with $3 \mathrm{~mL}$ of diluted Folin-Ciocalteu reagent and $2.5 \mathrm{~mL} 0.2 \%(\mathrm{w} / \mathrm{v})$ solution of $\mathrm{Na}_{2} \mathrm{CO}_{3}$. The mixture was allowed to stand for $30 \mathrm{~min}$ at room temperature (about $25^{\circ} \mathrm{C}$ ) and the results solution absorbance were read at $750 \mathrm{~nm}$ with a spectrophotometer. Total phenolic was determined by standard calibration curve and expressed equivalently as gallic acid per dry mass of corn silk samples ( $\mu \mathrm{g}$ GAE/g dry sample).

\section{Total Flavonoid}

Total flavonoids were determined by the modified colorimetric aluminum chloride method and routine hydrates were used as standard (Liu et al., 2011). Dilute solution 0.5 $\mathrm{mL}$ of corn silk extract in $2.5 \mathrm{~mL}$ of methanol was mixed with $3 \mathrm{~mL} 0.01 \mathrm{~mol} / \mathrm{L}$ alumunium chloride in methanol. Then the mixture was allowed to stand for $10 \mathrm{~min}$ at room temperature (about $25^{\circ} \mathrm{C}$ ). The results solution absorbance were read at $400 \mathrm{~nm}$ with a spectrophotometer. The total content of flavonoid was determined by routine calibration curve at a concentration of 0-100 $\mathrm{mg} / \mathrm{mL}$ in methanol and expressed equivalently as routine hydrate per dry mass of corn silk samples ( $\mu \mathrm{g} \mathrm{RE} / \mathrm{g}$ dry sample).

\section{Antioxidant Activity}

Antioxidant activity was measured with DPPH free radicals (Liu et al., 2011). Corn silk extract $(0.2 \mathrm{~mL})$ was added with $1 \mathrm{~mL} 0.2 \mathrm{mM}$ then a solution of DPPH methanol was prepared. The reaction was mixed and allowed to stand for $30 \mathrm{~min}$ in the dark. Absorbance was read at $517 \mathrm{~nm}$ with a spectrophotometer. The percentage of absorbance inhibition was calculated and plotted as a function of the concentration of standard extract and corn silk to determine the ascorbic acid concentration of equivalent antioxidants. The percentage of DPPH radical activity (\%) of the sample was calculated as follows:

RSA-DPPH $(\%)=\left[\frac{1 \text { - sample absorbance }}{\text { control absorbance }}\right] \times 100$ All tests were run in duplicate and the samples analysis were run in triplicate and average.

\section{Results and Discussion \\ Yield}

Based on the analysis of variance, it showed that the type of solvent affected significantly on amendment $(p<0.05)$. After being tested further using Duncan Multiple Range Test (DMRT) at 5\% level, the bar chart of the solvent type effect on amendment can be seen in Fig. 1. 


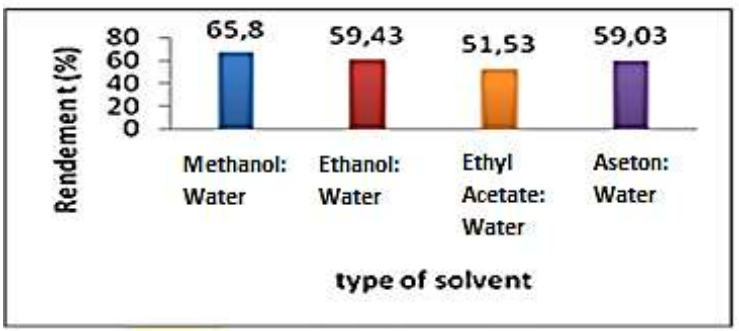

Fig. 1. Yield of corn silk extract

The results of DMRT test at $5 \%$ level indicated that there were significant differences among treatments. The yield differences were related to the differences in the polarity level in which the non-polar compounds will be soluble in nonpolar sol vents and the polar compounds will dissolve in polar solvents. The high dissolving power was associated with the solvent polarity and the extracted materials. According to Siedel (2008), the choice of solvent and extraction method will affect the outcome of the content of secondary metabolites which can be extracted. According to Samin et al., (2013), polar compounds were more concentrated on water fraction. The yield ethanol:water was higher than ethyl acetate:water. According to Harborne (1996), ethanol has two groups of different polarity, i.e the hydroxyl group which was polar and an alkyl group which was nonpolar. The existence of two groups of different polarity namely polar and nonpolar in ethanol solvent causing compounds that were nonpolar also extracted so that when they were extracted there were several compounds dissolved in them. Meanwhile, when they were extracted with ethyl acetate:water lower yield were obtained indicating that semi-polar compounds were not much extracted from the ethanol extract.

\section{Total Phenol}

Based on the analysis of variance, it showed that the type of solvent gave significant effect on the total phenol $(p<0.05)$. After being tested further using Duncan
Multiple Range Test (DMRT) at 5\% level, the bar chart of the solvent type effect on total phenols can be seen in Fig. 2 .

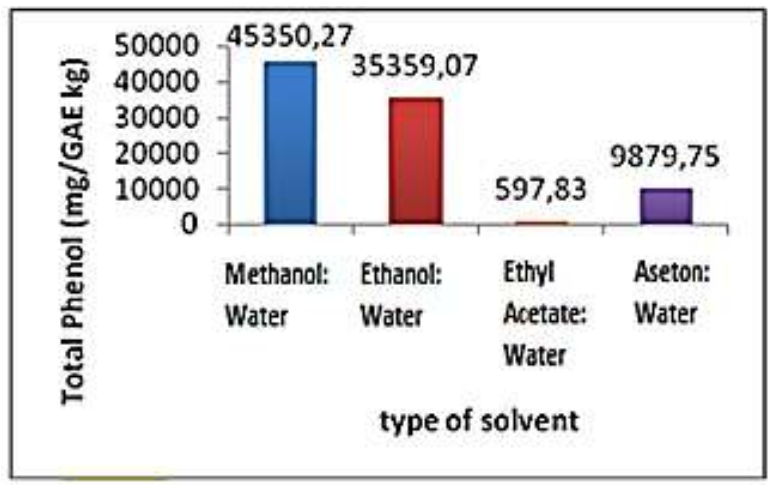

Fig. 2. Total phenol of corn silk extract

The test results of DMRT at $5 \%$ level indicated that among treatments were significantly different. The differences related to the compounds extracted in them, where solubility was greatly influenced by the polarity level of the solvent used. Phenol compound included a number of compounds commonly have an aromatic ring with one or more hydroxyl groups. The presence of the hydroxyl group caused polar phenol compounds to be polar that will be dissolved in polar solvents (Geissman and Crout, 1969). According to Moein and Mahmood (2010), the solvent which is polar is capable of dissolving phenol better. Phenol compounds on the corn silk which are polar include flavonoids, tannins, and saponins. Alkaloids and triterpenoids are semi-polar compounds and non-polar compounds are steroids. Othman et al., (2014) stated that the extraction of sample phenolic components depends on the compatibility of components with solvent systems based on principles "like dissolves like". Each solvent has different effectiveness in dissolving the phenolic compounds, depends on the suitability of the polarity of the solvent and phenolic compounds. Both phenolic and flavonoid compound are substances which have an 
aromatic ring with one or more hydroxyl groups so its nature is easily soluble in polar solvents. A Polar solvent capable of dissolving the phenol better so that the levels of total phenols and flavonoids in the extract becomes high.

\section{Total Flavonoids}

Based on the analysis of variance, it showed that the type of solvent gave significant effect on total flavonoids $(p<0.05)$. After being tested further using Duncan Multiple Range Test (DMRT) at 5\% level, the bar chart of the effect of the solvent type toward total flavonoid can be seen in Fig. $\mathbf{3}$.

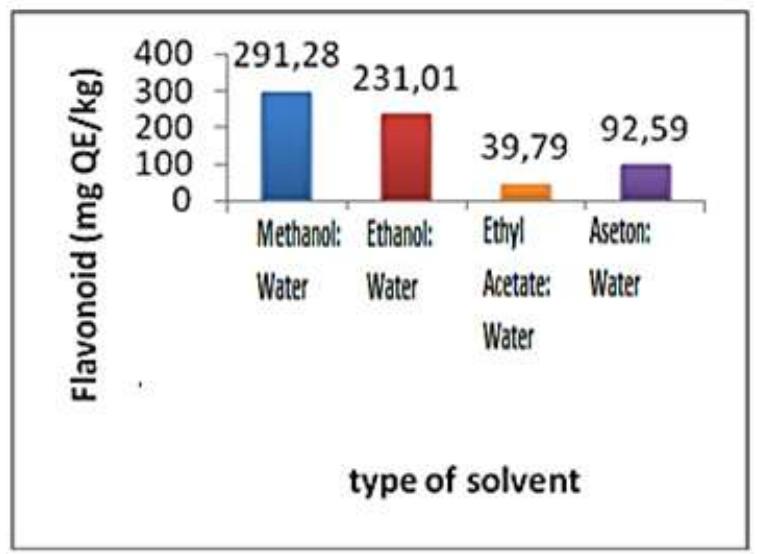

Fig. 3. Total flavonoids of corn silk extract

The test results of DMRT at $5 \%$ level indicated that there were significant differences among treatments. The differences indicated that flavonoid compounds contained in corn silk were dominated by polar compounds for the highest achievement was on methanol:water. Phenol compounds on corn silk which were polar included flavonoids, tannins and saponins. According to Rijke (2005), flavonoids are polar compounds as they have the number of hydroxyl groups which are not substituted.

\section{Antioxidant Activity}

Based on the analysis of variance, it showed that the type of solvent gave significant effect on antioxidant activity $(p<0.05)$. After being tested further using Duncan Multiple Range Test (DMRT) at level 5 , the bar chart of the effect of solvent type of antioxidant activity can be seen in Fig. 4 .

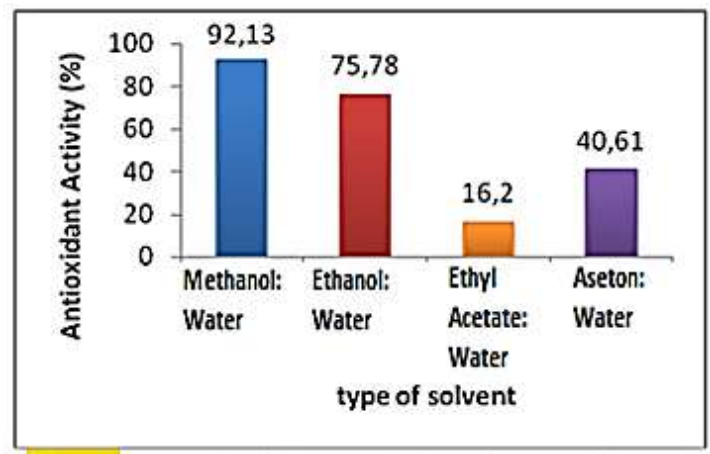

Fig. 4. Antioxidant activity of corn silk extract

The test results of DMRT at level $5 \%$ showed that there were significant differences among treatments. The high activity of DPPH free-radical scavengers on the extract methanol:water might be caused this extract has total phenol and flavonoid content higher than the ethanol:water, acetone: water and ethyl acetate:water. The activities of DPPH free-radical scavengers are related to the total amount of phenol in the plant tissue (Fernando and Soysa, 2014). The higher the content of phenols and flavonoids in the extract, the more the hydroxyl groups. The presence of hydroxyl groups in the molecule will increase capacity (Swarna et al., 2014). The results of this study are in line with the research of Nurcahyanti et al., (2011) which stated that the seeds of basil (Ocimum sanctum Linn) extracted with methanol has the highest ability of free radical inhibition in all concentrations than ethanol, acetone and ethyl acetate. 
DPPH is often used as a substrate to evaluate antiradical of antioxidants. This method is based on the reduction of DPPH solution that forms DPPH-H, non-radical compounds, because of the presence of hydrogen donation from antioxidants (Swarna et al., 2013). The ability of antioxidants as the catcher of free radicals is associated with the ability of the antioxidants as a proton donor. Various phenolic compounds may contribute to free radical trapping capacity with different capacities. The number of protons of hydrogen that can be donated is influenced by the number and position of the aromatic hydroxyl groups or hydroxyl of phenolic component (Lai et al., 2001, and Su et al., 2004).

\section{Conclusion}

The type of solvent affects significantly $(p<0.05)$ on yield, total phenol, total flavonoids and antioxidant activity.

The type of solvent with the highest results are the ratio (methanol: water), then the ratio (ethanol: water), next to the ratio (acetone: water) and the lowest ratio (ethyl acetate: water). At ratio (methanol: water), the yield obtained is $65.8 \%$, total phenol $45350.27 \mathrm{mg} / \mathrm{GAE} \mathrm{kg}$, total flavonoids 291.28 $\mathrm{mg} \mathrm{QE} / \mathrm{kg}$ and antioxidant activity $92.1 \%$.

\section{References}

Akcay, selcuk. 2011. The Causal relationship between producer price index and consumer price index: Empirical Evidence for Selected European Countries. International Journal of Economics and Finance. 3(6)

Bangoura, M.L., Nsor-Atindana, J., and Ming, Z.H. 2013. Solvent Optimization Extraction of Antioxidants from Foxtail millet Species Insoluble Fibers and their Free Radical Scavenging Properties. Food Chem. 141: 736-744
Burin, V.M., Rossa, P.N., Ferreira-Lima, N.E., Hillmann, M.C.R. and Boirdignon-Luiz, M.T. 2011. Anthocyanins: optimization of extraction from Cabernet Sauvignon grapes, microcapsulation and stability in soft drink. International Journal of Food Science \& Technology. 46: 186193.

Bushman, B.S. 2002. The genetic of chlorogenic acid synthesis in maize (PhD Dissertation). University of Missouri-Columbia, USA.

Chew, K.K, Ng.S.Y., Thoo, Y.Y., Khoo, M.Z., Wan Aida, W.M and Ho, C.W.2011. Effect of ethanol concentration, extraction time, and extraction temperature on the recovery of phenolic compounds and antioxidant capacity of Centella Asiatica extracts. International food Research Journal. 18:571-578.

Ebrahimzadeh, M.A., Pourmorad, F., and Bekhradnia, A.R., 2008. Iron chelating activity, phenol and flavonoid content of some medicinal plant from Iran. African Journal of Biotechnology. 7(18): 3188-3192.

Fernando, C and Soysa, P. 2014. Total phenolic, flavonoid contents, in vitro antioxidant activities and hepatoprotective effect of aqueous leaf extract of Atlanta Ceylan ICA. BMC complementary and alternative medicine the official journal of the International Society for Complementary Medicine Research (ISCMR).

Geissman, T.A and Crout DHG. 1969. "Organic chemistry of secondary plant". Metabolism. Freeman Cooper and Co, California.

Guo, J., Liu T, Han.L, and Liu. Y. 2009. The effect of corn silk on glycaemic metabolism. Journal Nutrition \& Metabolism Biomed Central. 6:47. 
Harbone, J.B. 1996. "Metode fitokimia penuntun cara modern menganalisis tumbuhan". Terbitan Kedua. Institut Teknologi Bandung, Bandung.

Hu, Q.L, and Deng, Z. 2011. Protective effects of flavonoids from corn silk on oxidative stress induced by exhaustive exercise in mice. African Journal of Biotechnology. 10:3163-3167.

Jayaprakasha G.K, Singh R.P, and Sakariah k.K. 2001. Antioxidant activity of grape seed (Vitis vinifera) extracts on peroxidation models in vitro. Food Chemistry. 73: 285-290.

Lai LS, Chou ST, and Chao WW. 2001. Studies on the antioxidative activities of Asian tsao (Mesona procumbens Heins) leaf gum. J. Agric. Food Chem. 49(2):963968.

Li, J., 2009. Total anthocyanin content in blue corn cookies as affected by ingredients and oven types. Dissertation. Department of Grain Science and Industry College of Agriculture. Kansas University, Manhattan, Kansas.

Liu, J, Wang C. Wang, Z, Zhang, and C. Lu, S. 2011. The antioxidant and free-radical scavenging activities of extract and fractions from corn silk (Zea mays L) and related flavone glycosides. Food Chemistry. 126: 261-269.

Nurcahyanti, A.D.R, Dewi L and Timotius, K.H. 2011. Aktifitas antioksidan dan antibakteri ekstrak polar dan nonpolar biji selasih (Ocimum sanctum Linn). Jurnal Teknologi dan Industri Pangan 1 (22):1-6.

Nurhanan, A.R, Rosli, W.I.W and Mohsin, S.S.J. 2012. Total polyphenol content and free radical scavenging activity of corn silk (Zea mays hairs). Sain Malysiana. 40 (2):155-161.

Nurhanan A.R and Rosli, W.I.W. 2014. Nutritional compositions and antioxidative capacity of the silk obtained from immature and mature corn. Journal of King Soud UniversityScience. 26: 119-127.

Nuridayanti, E.F.T. 2011. Uji Toksisitas Akut Ekstrak Rambut Jagung Ditinjau dari Nilai $L_{50}$ dan Pengaruhnya Terhadap Fungsi Hati dan Ginjal pada Mencit. Skripsi. Universitas Indonesia, Jakarta.

Moein S dan Mahmood RM. 2010. Relationship between antioxidant properties and phenolics in Zhumeria majdae. Journal of Medicinal Plants Research (7):517-521.

Othman A, Mukhtar N.J, Ismail N.S, Chang S.K. 2014. Phenolics, flavonoids content and antioxidant activity of 4 malaysian herbal plants. International Food Research Journal 21 (2):759-766.

Rahmayani, A.2007. Telaah kandungan kimia rambut jagung (Zea mays L). Institut Pertanian Bogor, Bogor.

Rijke, E. 2005. "Trace-level determination of flavonioids and their conjugates". Application in plants of the leguminose family. Universitas Amsterdam, Amsterdam.

Samin, A.A, Bialangi N, and Salimi Y.K. 2013. "Determination of total phenolic content and antioxidant activity of hair corn (Zea mays L) that grows in the region of Gorontalo". Gorontalo University, Gorontalo.

Sholihah, M.A., Nurhanan, A.R., and Wan Rosli, W.I. 2012. Phytochemicals screening and total phenolic content of malaysian Zea mays hair extracts. International Food Research Journal. 19(4): 1533-1538.

Siedel, V. 2008. Initial and bulk extraction. In "Natural Products Isolation $2^{\text {nd". }}$ ed. Sarker, S.D., Latif, Z. and Gray, A. I, pp.33-34. Humana Press, New Jersey.

Su, Y.L, Xu, J.Z, Ng, C.H, Leung, L.K.K, Huang, Y. and Chen ZC. 2004. Antioxidant activity 
of tea theaflavins and methylated. Catecin in Canola Oil. JAOCS 31(3):269274.

Swarna, J, Lokeswari T.S, Smita M, and Ravindhran R. 2013. Characterisation and determination of in vitro antioxidant potential of betalains from Talinum trangulare (Jacq.) Willd. Food Chemistry. 141:4382-4390.

Swarna L.G, Sandhaya B, Jayachandra P.R, Jayaveera K.N, Subramanyam S. 2014. Antioxidant activity of methanolic extract of flower of Commelina clavata. International Journal of Phytopharmacology. 5(4): 288-292.
Tong-Wei, J., Jian, X., Xiao-Meng, W., XueSong, C., and Zhi-Dong, Q. 2011. Screening of active ingredient of Stigmata maydis inhibitor xanthine oxidaseand its effect. Journal of Jilin University Medicine Edition. 37(3): 433436.

Wang, C.Z, Liu, T., Lu, J., Zhang, S., Wang, C., Wang, E., Zhang, Z.Y. and Liu, J. 2011. Subchronic toxicity study of corn silk with rats. Journal of Ethnopharmacology. 137:36-43.

Wiryowidagdo, S dan Sitanggang, M. 2004. "Tanaman obat untuk penyakit jantung, darah tinggi dan kolesterol".Agromedia Pustaka, Jakarta. 